\title{
Effects of long-term mixed land use of human settlement and oil palm plantation on the groundwater quality of ex-promontory land.
}

\author{
SitiZulaikhaOthman ${ }^{1,2}$, RoslanHashim $^{1}$, Mohamad \\ FaizalTajulBaharuddin ${ }^{3}$,SharifahMohamad ${ }^{4}$. \\ ${ }^{I}$ (Department of Civil Engineering, Faculty of Engineering, University of Malaya, 50603 LembahPantai, Kuala \\ Lumpur, Malaysia). \\ 2 (Institute of Biological Sciences, Faculty of Sciences, University of Malaya, 50603 LembahPantai, Kuala \\ Lumpur, Malaysia). \\ ${ }^{3}$ (Department of Water and Environmental Engineering, Faculty of Civil and Environmental Engineering, \\ University Tun Hussein Onn, 86400 Parit Raja, BatuPahat, Johor, Malaysia). \\ ${ }^{4}$ (Department of Chemistry, Faculty of Sciences, University of Malaya, 50603 LembahPantai, Kuala Lumpur,
} Malaysia).

\begin{abstract}
This paper focused on the quality of groundwater at the ex-promontory-land of Carey Island to study agricultural impacts on groundwater aquifers. Groundwater quality was measured regularly by using ion chromatography from November 2010 to April 2012. High amount of ammonium-nitrogen $\left(\mathrm{NH}_{4}-\mathrm{N}\right) \sim 36.06 \mathrm{mgL}^{-}$ ${ }^{1}$, nitrate-nitrogen $\left(\mathrm{NO}_{3}-\mathrm{N}\right) \sim 33.82 \mathrm{mgL} L^{-1}$, phosphate ions $\left(\mathrm{PO}_{4}^{3-}\right) \sim 18.03 \mathrm{mLL}^{-1}$ and potassium ions $\left(\mathrm{K}^{+}\right) \sim$ $151.77 \mathrm{mgL}^{-1}$ were found in the groundwater indicating the impact of fertilizers application on the land formore a century period. Other physical parameters such as water temperature,groundwater table, total dissolved solids (TDS), $p H$, and electrical conductivity (EC) were also determined to trace out the groundwater quality trends. It is found that the difference in groundwater quality based on unconfined and semi-confined aquifers was not significant. Cluster analysis (CA), principal component analysis (PCA) and multivariate analysis (ANOVA) were employed to characterize the hydrogeochemical of the groundwater. Three clusters are developed according to the water quality variables and the loadings feature in PCA confirms the factors of groundwater contamination.
\end{abstract}

Keywords: Ex-promontory land; fertilizers; groundwater; hydrogeochemical; nutrients

\section{Introduction}

It is known that the use of fertilizers in the long run will affect the quality of the water and soil in the particular area especially where the plantation activities has been running for decades. In Malaysia for examples, the main agriculture product is from oil palms and many areas are transformed to oil palm plantation area. Nitrogen $(\mathrm{N})$, phosphorus $(\mathrm{P})$ and potassium $(\mathrm{K})$ are common elements in fertilizers required by oil palms to maximize the productivity. The application of excessive fertilizer or scheduled fertilizing will give impact to surface and groundwater due to nutrient leaching. The residues may seep to the surrounding water body and cause water pollution.

This study reports the condition of groundwater quality in Carey Island, Klang, Malaysiato assist in freshwater exploration at the area that has been carried out by the authorities for years. To date, there is no study of groundwater quality in active plantation area as there was no human settlement which is different with Carey Island. The review will assist local authorities and villagers to plan future freshwater supply and help the socioeconomic of the area based on the agriculture and natural resources.

Most of the population depends on marine and mangrove products apart from working in the plantation. The most important is to monitor the level of pollution from plantation activities so that the sensitive ecology of the island can be conserved.

The island was a natural promontory land of Selangor; however in early $19^{\text {th }}$ century a little strip of land separating the river and the strait was broken through and it became one of islands of the Selangor state. Sir Edward Valentine Carey, a British planter openedthe area for rubber plantation in early 1900's and now $65 \%(10,521.84 \mathrm{ha})$ of the island's total land is transformed to oil palm plantation with the rest is being conserve as a mangrove area. Because of its long distance from Langat and Semenyih Dams, this area does not receive upper-catchment surface freshwater, even though piped surface-water supply was commissioned in the late 1990's.Despite the lack of water facilities, there are about 10, 000 people living in the area consisting of estate workers, local villagers and aborigines (MahMeri). For decades, most of the population here relies on the groundwater and harvest rainwater as their freshwater source. 
In order to ensure that everybody receives proper freshwater facilities, the Malaysian government have taken initiatives and appointedthe Department of Mineral and Geosciences Malaysia, under the Ministry of Natural Resources and Environment to investigate the water supply potential and suitability of using hand-pump in the rural areas of Kuala Langat District, Selangor [1]. Construction and exploration of deep wells at Carey Island andKelanang village in the district were also conducted to seek groundwater resources [2].Recently, a further study has been carried out to determine the occurrence of freshwater lens and seawater intrusion in the island [3-5]. Other studies on contamination of aquifers and water sources have also been conducted [6-9].

The use of fertilizer for agriculture is the main non-point pollution source in Carey Island rural catchments. Nutrient leaching causesgroundwater minerals content to exceed local water quality standards especially at the unconfined aquifer where it is a sandy region. This region is just $1.5 \mathrm{~km}$ away from the shoreline, where the possibility of nutrient leaching towards the sea is high. Discharge of groundwater from agricultural land towards the water system may cause exceedance of surface water quality standard as well [10]. The most problematic inorganic agrochemicals are nutrients $\left(\mathrm{NH}_{4}-\mathrm{N}, \mathrm{NO}_{3}-\mathrm{N}, \mathrm{PO}_{4}{ }^{3-}\right.$ and $\left.\mathrm{K}^{+}\right)$which are the main compounds in fertilizers.

Other causes of contamination are seepage from waste containments and seawater intrusion [11-15] and spills [16-19] causing changes in the geochemistry of the area and affecting the quality of the water for agricultural and drinking purposes $[20,21]$. The water needs to be cleaned up through several means of remediation [22-25] guided by established standards [26].

\section{Description Of The Study Area}

Carey Island is situated in the Selangor state and well known as a vast plantation island. It is located on the west coast of the Selangor state in West Peninsular Malaysia between LAT, $2^{\circ} 50^{\prime} 3.07^{\prime \prime}$ andLAT, $2^{\circ} 57^{\prime} 49.51^{\prime \prime}$ and between LONG, $101^{\circ} 17^{\prime} 25.16^{\prime \prime}$ andLONG, $101^{\circ} 26^{\prime} 18.37^{\prime \prime}$ (Fig. 1).

The total area of Carey Island is 16,187.45 ha representing about 6\% of Langat Basin area.There are $1,876.85$ ha of mangrove forest area on the south-west of Carey Island which comprises of rivers, coastal areas and estuaries. Hence, it is important to assess and monitor the surface and groundwater quality of this area as the ecology is very sensitive to the pollutant mainly from the plantation activities.

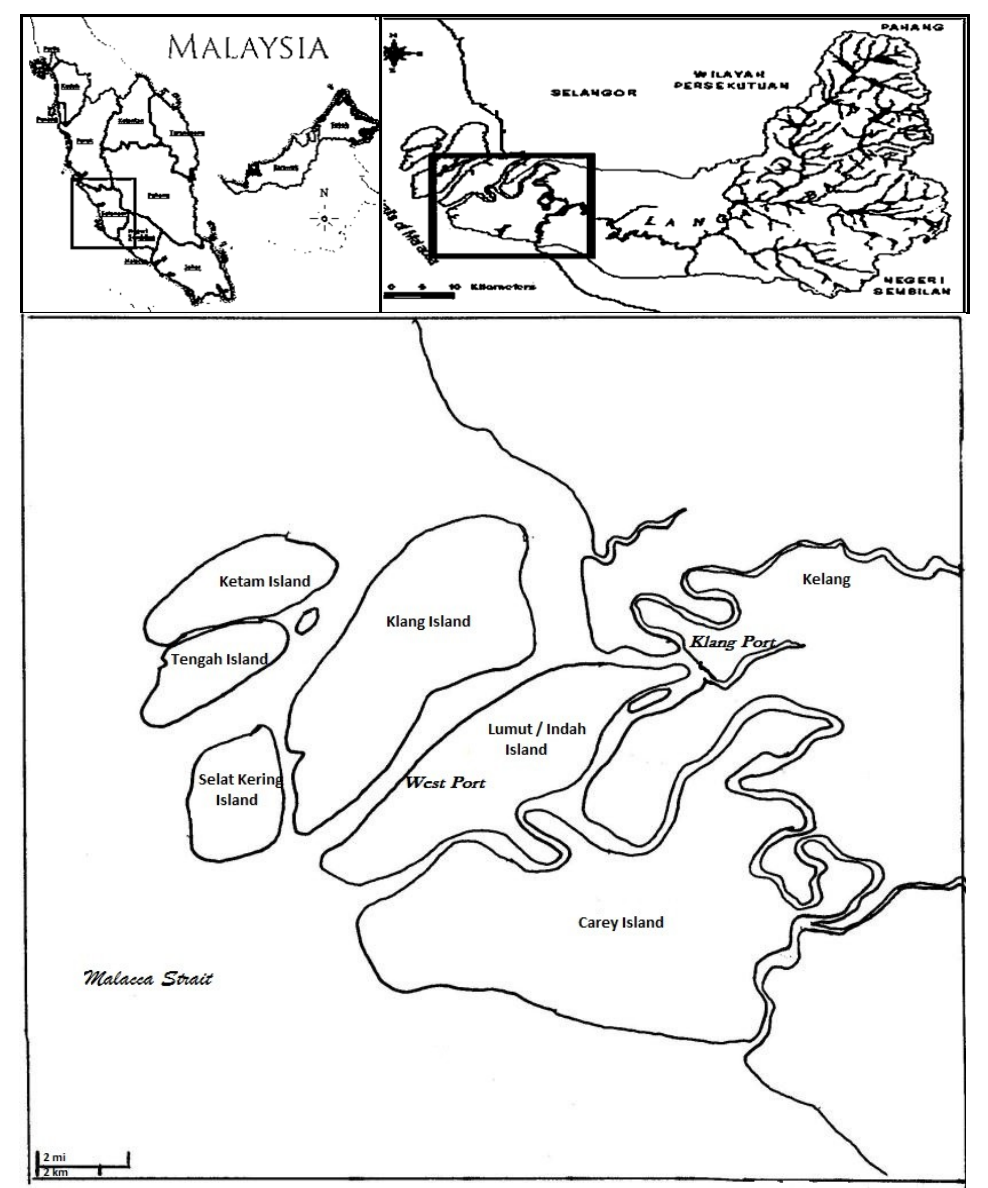

Figure 1: Map of Carey Island with neighboring islands in Selangor state and Langat Basin coverage. 


\subsection{Groundwater quality monitoring in the study area}

Groundwater quality monitoring is carried out from 13 deep boreholes that have beendrilled around 2009 for extensive study (Fig. 2). The area was chosen based on the human settlement and distance from coastal area. From the earlier survey, it is found that the area of monitoring wells can be divided to semi-confined and unconfined aquifer. For semi-confined aquifer, boreholes arelabeled asMW1, MW2, MW3, MW4, MW8, MW9 with the thickness of the uppermost semi-impermeable layer varying from 27.0 to $31.5 \mathrm{~m}$ below ground surface. The aquifer reaching between 60 and $66 \mathrm{~m}$ with soil type was light gray, marine and silty clay. Whereas for unconfined aquifer boreholes are labeled as MW6, MW7, MW10, MW11, MW12, MW13and MW14 with the first aquifers found from 10 to 60 mdeep from the ground level. It is comprised of fine-to-coarse light-grey sand and gravel, impermeable materials (silt and clay), and fragmented shells. The presence of fragmented shells confirmed that the layers were deposited by a marine environment[4].

At first, the groundwater quality is analysed based on the type of aquifers which are semi-confined and unconfined to assess the severity of contamination. The extensive data then analysed by chemometrics / environmentrics to have better understanding on the geochemistry of the groundwater. Therefore, the objective of the study is to evaluatethe physico-chemicals properties in the groundwater as a result of the impact of oil palm plantation and to save time for future freshwater exploration as well as assistingin water management.

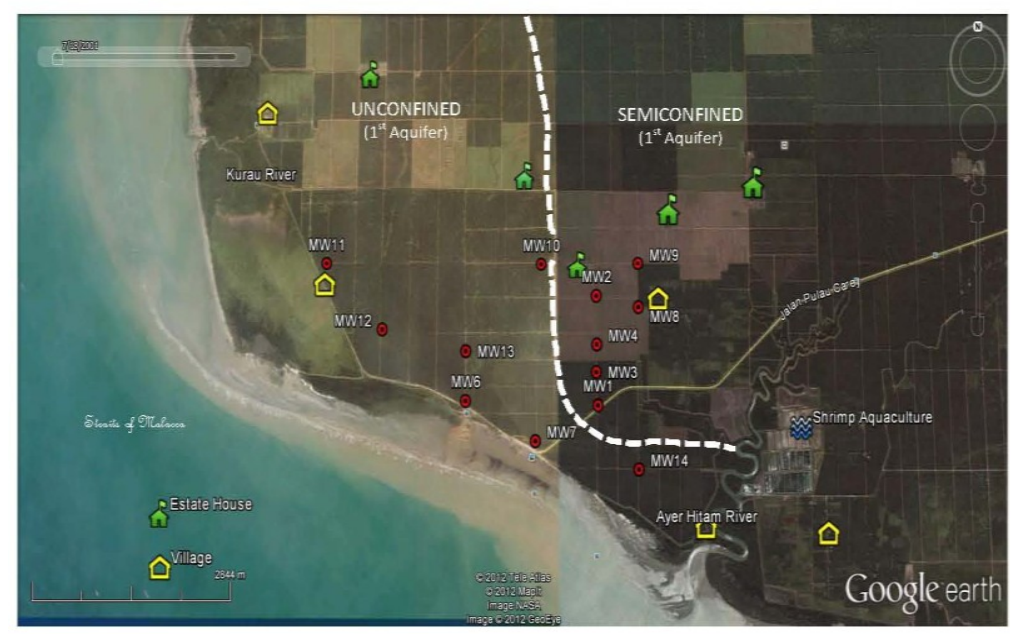

Figure 2: Location of monitoring wells, estate houses and villages.

\section{Materials And Methods}

Water samplings have been carried out for duration from November 2011 to April 2012. Some water quality parameters were sampled in situ and some were analysed in the laboratory. Temperature, electrical conductivity (EC), salinity, $\mathrm{pH}$ and total dissolved solids were measured in situ by using multiparameters meter IQ Scientific Instruments (Hach, USA). Groundwater table is also measured using water level TLC Meter Model 107 (Solinst, Canada). For nutrients, water samples were kept in polyethylene bottles in cool temperature before it is kept in refrigerator at $4^{\circ} \mathrm{C}$ prior to laboratory analysis. Groundwater has been sampled by using biodegradable plastic bailers from monitoring wells and was preserved in two separate bottles with and without concentrated sulphuric acid to prohibit further chemical reaction in the water. Most of the water samples wereanalysedimmediately according to the standard method [29] by using Ion Chromatography 850 Professional IC (Metrohm, Switzerland) for cations analyses such as nitrate-nitrogen $\left(\mathrm{NO}_{3}-\mathrm{N}\right)$ and phosphate ions $\left(\mathrm{PO}_{4}{ }^{3-}\right)$, whilst anions; ammonium-nitrogen $\left(\mathrm{NH}_{4}-\mathrm{N}\right)$ and potassium ions $\left(\mathrm{K}^{+}\right)$were analysed by using Ion Chromatography Model ICS-1100 System (Dionex, USA).

\section{Results And Discussion}

\subsection{The effects of intensive agriculture on the quality of the groundwater.}

Groundwater monitoring in Carey Island is divided to semi-confined and unconfined aquifer. The average water temperature for the period of November 2010 to April 2012 was in the range of 28.6 to $31.3^{\circ} \mathrm{C}$ (Table 1). The water temperature showed that the groundwater was not affected by any earth activity that involves heat. However, there were still differences in water temperature between monitoring wells depending on their location. For examples, MW1and MW6 were exposed directly to the sun whilst the others are under oil palm foliage. On the other hand, groundwater tables fluctuated and showed that they were affected by the seawater. It can be seen by the distance of the monitoring wells from the shorelines, for examplesMW6, MW7, MW11 and MW14 (Fig. 2 \& Table 1). 
Table 1: Water temperature and groundwater tables at the monitoring wells.

\begin{tabular}{lcc}
\hline Monitoring Well & Temperature $\left({ }^{\mathbf{0}} \mathbf{C}\right)$ & Groundwater table (m) \\
Semi-confined (1 ${ }^{\text {st }}$ Aquifer) & & \\
MW1 & $30.5 \pm 0.4$ & $0.77 \pm 0.07$ \\
MW2 & $29.4 \pm 0.2$ & $1.01 \pm 0.07$ \\
MW3 & $29.2 \pm 0.7$ & $0.94 \pm 0.04$ \\
MW4 & $28.9 \pm 0.3$ & $1.08 \pm 0.15$ \\
MW8 & $28.9 \pm 0.4$ & $0.54 \pm 0.32$ \\
MW9 & $28.9 \pm 0.5$ & $0.44 \pm 0.13$ \\
& & \\
Unconfined (1 ${ }^{\text {st }}$ Aquifer) & & $0.98 \pm 0.08$ \\
MW6 & $29.7 \pm 0.5$ & $1.35 \pm 0.11$ \\
MW7 & $28.6 \pm 0.4$ & $1.02 \pm 0.03$ \\
MW10 & $29.5 \pm 0.6$ & $1.25 \pm 0.03$ \\
MW11 & $29.0 \pm 0.4$ & $0.78 \pm 0.06$ \\
MW12 & $29.5 \pm 0.2$ & $0.77 \pm 0.38$ \\
MW13 & $29.4 \pm 0.5$ & $1.22 \pm 0.07$ \\
\hline
\end{tabular}

MeanwhileMW4is located near the main irrigation which accounts for the high groundwater table. Overall, it can be concluded that groundwater tables were higher in the unconfined compared to semi-confined area due to the sandy region near the shoreline. The $\mathrm{pH}$ of water was also compared for all monitoring wells. It is found that $\mathrm{pH}$ of groundwater was in theoptimal range which is 6.6 and 8.1(Fig. 3).pH of groundwater is much influenced by the $\mathrm{pH}$ of the soil; hence, liming is conducted to increase the $\mathrm{pH}$ of the soil to a pH level where more soil nutrients can be available for plant use since high $\mathrm{pH}$ reduces availability of soil nutrients.

Meanwhile, total dissolved solids (TDS) levels in the groundwater were above 1 ppt which exceeded the allowed level for Class IIA of Malaysian National Water Quality Standard (NWQS). This class requires water to go through conventional treatment before it can be used as a water supply and some aquatic species are sensitive at this level of water quality. The average groundwater conductivity falls in Class IV of NWQS (6 $\mathrm{mS} / \mathrm{cm}$ ) which is suitable for irrigation of crops purposes [6]. The high conductivity readings (up to 16.4 $\mathrm{mS} / \mathrm{cm}$ ) of the most monitoring wells show disturbances in groundwater quality of the island. Groundwater in both semi-confined and unconfined aquifers can be classified as brackish water which the salinity was more than 1 ppt. However, for MW10 and MW11, they had the lowest reading for TDS, conductivity and salinity, and almost reached freshwater level. TDS, EC and salinity were closely related to each other and they had the same trends. The high TDS and EC were correlated to salinity $(\mathrm{NaCl})$ concentration which will not be discussed in this paper.

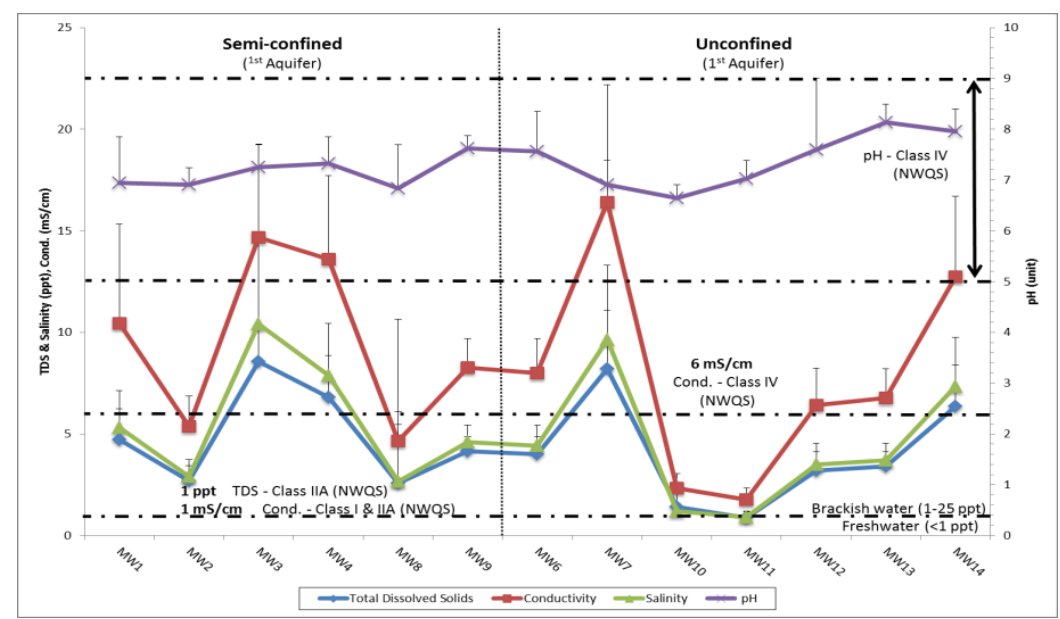

Figure 3: Average total dissolved solids, conductivity, salinity and pH from Nov 2010 to Apr 2012.

The NPK fertilizer or chemical fertilizer is the main contributor for macro-nutrients required by the oil palm. $\mathrm{N}$ is important in improving oil palm leaf growth and it will turn yellow-green or pale with deficient of $\mathrm{N}$ nutrient. A mature oil palm tree needs an intake of $0.25-1.75 \mathrm{~kg}$ of $\mathrm{N}$ per palm tree per year. Ammonia fertilizer is added in the soil in order to improve the $\mathrm{N}$ nutrient. As expected, ammonium-nitrogen $\left(\mathrm{NH}_{4}-\mathrm{N}\right)$ is found quite high in groundwater and exceed the Malaysian NWQS of Class V which is more than $2.7 \mathrm{mg} / \mathrm{L}$ (Fig. 4). The highest average concentrations of $\mathrm{NH}_{4}-\mathrm{N}$ were recorded at MW11 with $27 \mathrm{mgL}^{-1}$ and MW14with $15 \mathrm{mgL}^{-1}$. 
Generally, in unpolluted waters $\mathrm{NH}_{3}$ and $\mathrm{NH}_{4}$ compounds occur in relatively small quantities, usually on the order of $1 \mathrm{mgL}^{-1}$ or less [27].

Nitrate $\left(\mathrm{NO}_{3}{ }^{-}\right)$causes the most concern in terms of pollutant in the freshwater source. High content of nitrate in water is always related to waste, animal manure and chemicals in fertilizers. The effect of nitrate pollution in the drinking water is widely discussed in the literature. In the case of Carey Island, it is found that nitrate-nitrogen $\left(\mathrm{NO}_{3}-\mathrm{N}\right)$ content in the groundwater was high with the concentration was up to $30 \mathrm{mgL}^{-1}$. Fig. 4 shows that most of the groundwater samples were above $7 \mathrm{mg} / \mathrm{L}$ which is the allowable level for Class IIA\&IIB in the National Drinking Water Quality Standard (NDWQS). The average $\mathrm{NO}_{3}-\mathrm{N}$ concentrations were recorded high at MW3, MW4, MW6 and MW14 in the range of $17 \mathrm{mgL}^{-1}$ to $30 \mathrm{mgL}^{-1}$. $\mathrm{NO}_{3}-\mathrm{N}$ usually occurs in relatively small concentrations in unpolluted freshwater in about $0.3 \mathrm{mgL}^{-1}[27]$.

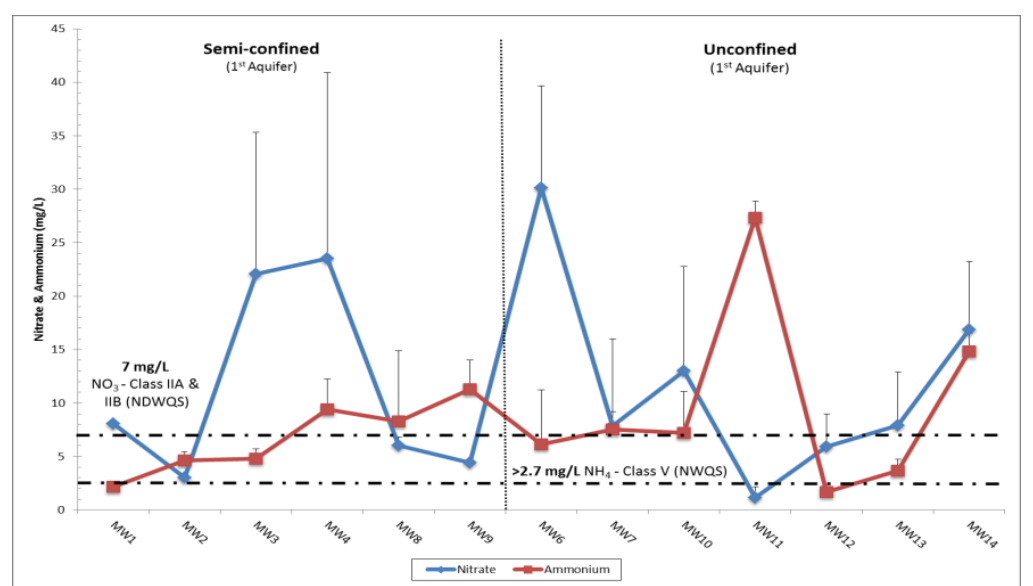

Figure 4: Average nitrate and ammonium concentration from Nov 2010 to Apr 2012.

It is believed that the high concentration of $\mathrm{NH}_{4}-\mathrm{Nand} \mathrm{NO}_{3}-\mathrm{N}$ is because of the long term usage of fertilizers. In Malaysia, common nitrogen fertilizers used in oil palm plantation are ammonium sulphate $\left[\left(\mathrm{NH}_{4}\right)_{2} \mathrm{SO}_{4}\right]$, ammonium nitrate, ammonium chloride and urea. As for Sime Darby oil palm plantation, they use ammonium sulphate $(21 \% \mathrm{~N})$ and water soluble polyphosphateas phosphorus source for immature palms. For mature palms phosphate rocks or known as phosphorite are applied as it is more effective and economic.

Phosphorus $(\mathrm{P})$ is the nutrient for increasing the frond weight which associated with oil palm bunch fruit size. A deficiency of $\mathrm{P}$ will reduce palm trunk diameter and smaller bunch size. It is recommended to add $0.4-0.7 \mathrm{~kg}$ of $\mathrm{P}$ per palm tree per year. On average, most of the phosphate $\left(\mathrm{PO}_{4}{ }^{3-}\right)$ concentration in the groundwater was high which was up to $7.58 \mathrm{mg} / \mathrm{L}$ at MW3.It is worth to highlight that there were records of high $\mathrm{PO}_{4}{ }^{3-}$ concentration on the particular sampling days for examples 123.64 and $46.88 \mathrm{mg} / \mathrm{L}$ in MW1 in the same month, $28.89 \mathrm{mg} / \mathrm{L}$ (MW6) and $89.84 \mathrm{mg} / \mathrm{L}$ (MW13). However, the data were taken out during statistical analysis as they were classified as outlier data which means they were out of data normal distribution. It might be on the day water sampling was carried out; it was just a few days after routine scheduled fertilizing at the particular area. Meanwhile, at some sampling points such as MW7,MW9 and MW10;phosphate content in the water was not detected as the level content was very low probably due to flash losses of soluble phosphate. Standard deviation for each monitoring wells is high because of the fluctuation in the reading.

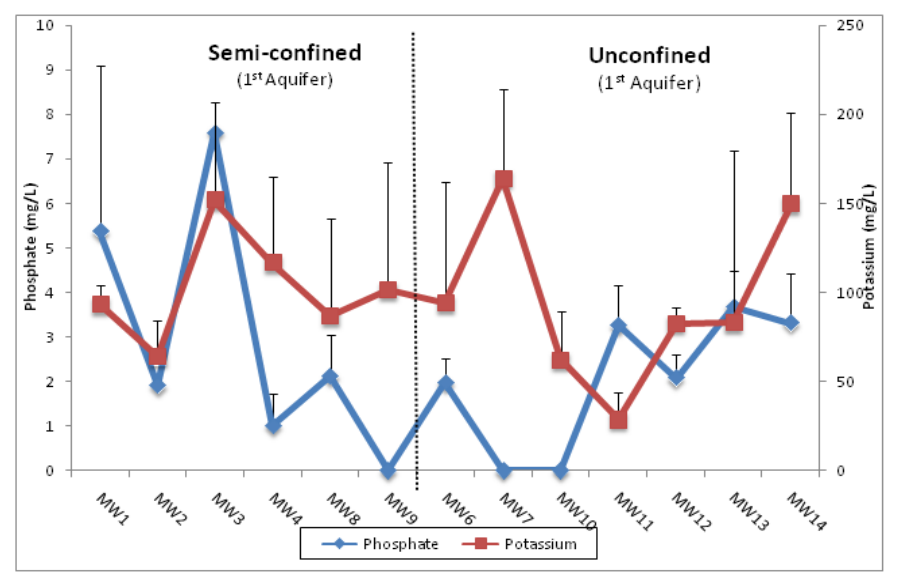

Figure 5: Average phosphate and potassium concentration from Nov 2010 to Apr 2012. 
Soil management practices also could affect $\mathrm{P}$ concentration in the soil. There were findings at the oil palm plantation that had not been fertilized for fifteen years showed that there was a variation between available $\mathrm{P}$ at top soil $\left(0-30 \mathrm{~cm}\right.$ soil depth) in the range of $1.09-4.82 \mathrm{mgkg}^{-1}$ and subsoil $(30-60 \mathrm{~cm}$ soil depth) in the range of $0.27-8.18 \mathrm{mgkg}^{-1}$ [28]. The poor chemical condition of the groundwater can lead to

the exceedance of the quality standards in receiving surface waters even though they are not influenced by other resources [10]. The high content of $\mathrm{PO}_{4}{ }^{3-}$ also will intoxicate the aquatic organisms especially the bivalve species. This matter becomes a concern because it could be a loss and harm the local people as the beach in this area is popular among the cockle farmers.

Potassium or kalium $(\mathrm{K})$ is one of the major components in fertilizers. $\mathrm{K}$ is important for oil palm resistance to deceased and drought tolerance. A palm could adapt from $0.3-3 \mathrm{~kg}$ of $\mathrm{K}$ palm tree per year. $\mathrm{K}^{+}$ concentration was found high at MW1 and MW3 where both at semi-confined aquifer. The high concentration of $\mathrm{K}^{+}$in soil and water could be fixed by the presence of high exchangeable aluminium and iron ions and their oxides. $\mathrm{K}$ deficiency is very common and is the major yield constraint in sandy or peat soils. Even thoughorganisms can tolerate with high $\mathrm{K}^{+}$concentration; the exceedance concentration in the water will also harm. For examples, $\mathrm{LD}_{50}$ values of $\mathrm{K}^{+}$are $132 \mathrm{mgL}^{-1}$ for fish and $1.16 \mathrm{mgL}^{-1}$ for daphnia a planktonic organism that serve as an important source of food for fish and other aquatic organisms.

There were no significant differences in all parameters measured between semi-confined and unconfined aquifers except for groundwater table ( $\mathrm{Pt}$-test $=0.042 ; \mathrm{df}=11 ; \mathrm{p}<0.05)$ (Table 2). Groundwater table at the unconfined aquifer was significantly higher than the semi-confined aquifers. Hence, chemometrics or environmentricsanalysis has been carriedout to characterize the hydrogeochemical of groundwater based on the available data.

\begin{tabular}{|l|r|r|}
\hline \multicolumn{2}{|c|}{ Table 2: Mean comparison of t-Test for groundwater tables. } \\
\hline & & Unconfined \\
\hline Mean & Semiconfined & 1.052452381 \\
\hline Variance & 0.795146825 & 0.052437115 \\
\hline Observations & 0.068345544 & 7 \\
\hline Pooled Variance & 6 & 7 \\
\hline Hypothesized Mean Difference & 0.059668219 & 0 \\
\hline df & 11 & \\
\hline Stat & -1.893348648 & \\
\hline$P(T<=t)$ one-tail & $0.042450196 *$ & \\
\hline Critical one-tail & 1.795884819 & \\
\hline$P(T<=t)$ two-tail & 0.084900391 & \\
$t$ Critical two-tail & 2.20098516 & \\
\hline
\end{tabular}

**highly significant $(\mathrm{p}<0.01) ; *$ significant $(\mathrm{p}<0.05)$; ns not significant $(\mathrm{p}<0.05)$

\subsection{Chemometrics / Environmetrics analysis}

It is important to use correct and suitable methods to interpret a huge amount of data.Chemometrics or environmetrics can be considered as a branch of environmental analytical chemistry that uses multivariate statistical modelling and it is deemed to be the best approach to avoid misinterpretation of a large complex environmental monitoring data[29].These methods have often been used in exploratory data analysis tools for classification of samples or sampling stations and identification of pollution sources [30,31]. It is also has been widely used in characterizing and evaluating the surface and groundwater quality.

\subsubsection{Cluster analysis (CA)}

Hierarchical agglomerative cluster analysis (HACA) was employed to investigate the similarity of groundwater character based on water quality parameters or variables. It is a common method to classify variables into clusters with high homogeneity level within the class and high heterogeneity level between classes with respect to a predetermined selection criterion.The Euclidean distance (linkage distance) between normalized data was used to detect multivariate similarities between samples by using water quality variables. Ward's method was applied to unscaled data and the results obtained were represented in a dendogram (Fig. 6).Ward suggested a general agglomerative hierarchical clustering procedure, where the criterion for choosing the pair of clusters to merge at each step is based on the optimal value of an objective function that reflects the investigator's purpose. From the dendogram, it shows that at the level of 60(the dashed line) the monitoring wells can be clustered into three groups based on the similarity of water quality variables and not the type of aquifers which are unconfined and semi-confined aquifer. All monitoring wells or members in each cluster were divided to Cluster 1 were MW1, MW4, MW6, MW7, MW8, MW12 and MW13, Cluster 2 were MW2, MW10 and MW11, and Cluster 3 were MW3, MW9, andMW14. Y-axis representing the similarity level was 
standardized by the equation;

(Dlink/Dmax) x 100

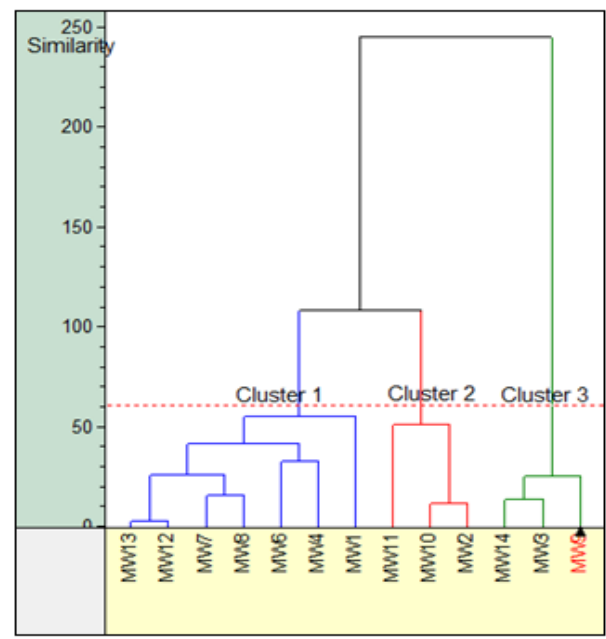

Figure 6: A dendogram showing three clusters at similarity index 60.

\subsubsection{Factor Analysis (FA) with Principal Component Analysis (PCA)}

Factor analysis (FA) with principal component analysis (PCA) provides information on the most significant parameters that describes the whole dataset by excluding the less significant parameters with minimum loss of original information. It is also can be used for structure detection which is to examine the underlying (or latent) relationships between the variables. Fig. 7show the scores of the sampling sites in a space formed by the two first PC's (PC1 andPC2) accounting for 99.07\% total variance (Table 3). The scores plot clearly shows three linearly separable clusters which are Cluster 1, Cluster 2 and Cluster 3 . These groups were similar to hierarchical agglomerative cluster analysis (HACA) results based on Euclidean distance and Ward's method. All three clusters were significantly differentfrom each other based on water quality variables factor (Table 4). From analysis, the result shows that the difference between clusters is highly significant (Two-way ANOVA: $\left.\mathrm{F}_{[2,8]}=38.11, \mathrm{p}<0.05\right)$ and also the interaction between clusters and water quality variables [Two-way ANOVA: $\left.\mathrm{F}_{[2,8]}=24.77, \mathrm{p}<0.05\right)$.

Table 3: Variances of PCA for the first six PCs.

\begin{tabular}{|c|c|c|}
\hline $\mathrm{PC}$ & Variance $(\%)$ & Total variance \\
\hline 1 & 98.02 & 98.02 \\
\hline 2 & 1.04 & 99.07 \\
\hline 3 & 0.54 & $99.61^{-}$ \\
\hline $\begin{array}{l}4 \\
5 \\
6\end{array}$ & $\begin{array}{l}0.26 \\
0.09 \\
0.03\end{array}$ & $\begin{array}{c}99.87 \\
99.96 \\
100\end{array}$ \\
\hline
\end{tabular}

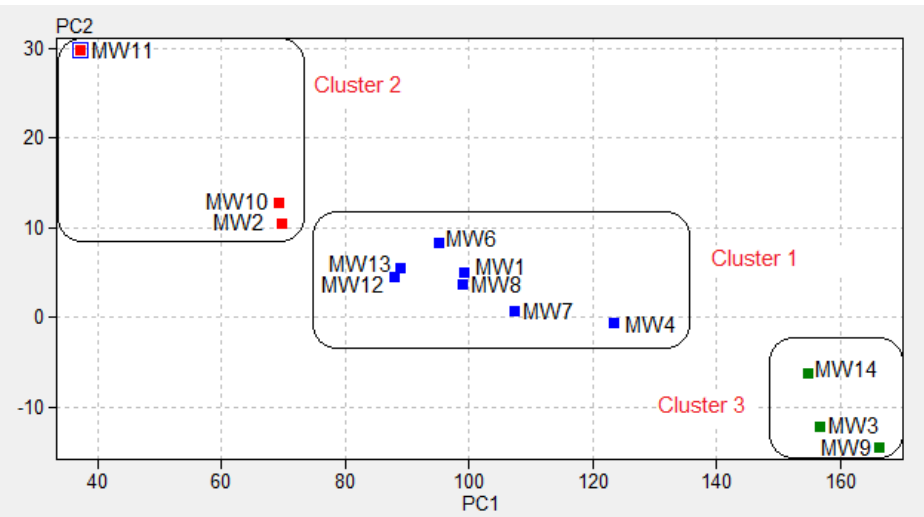

Figure 7: $\mathrm{PC} 1 / \mathrm{PC} 2$ scores in principal component analysis for 13 sampling sites. 
Table 4: Summary of all effects of Two-way ANOVA for clusters and water quality parameters.

\begin{tabular}{lcccccc} 
Two-way ANOVA & \multicolumn{7}{c}{ F } & F & P-value & F crit \\
\hline Source of Variation & SS & df & MS & F & $3.76667 \mathrm{E}-11$ & 3.168246 \\
Clusters & 2735.782 & 2 & 1367.891 & $38.11066^{* *}$ & $2.04587 \mathrm{E}-39$ & 2.15223 \\
Parameters & 69297.14 & 8 & 8662.142 & $241.3349^{* *}$ & 2.034629 \\
Interaction & 14224.47 & 16 & 889.0293 & $24.76914^{* *}$ & $3.07105 \mathrm{E}-19$ & 1.83462 \\
Within & 1938.201 & 54 & 35.89261 & & & \\
Total & 88195.59 & 80 & & & & \\
\hline
\end{tabular}

**highly significant $(\mathrm{p}<0.01) ;{ }^{*}$ significant $(\mathrm{p}<0.05)$; nsnot significant $(\mathrm{p}<0.05)$

In PCA, only prominent factors are counted for analysis to find the significant difference between the samples. Fig. 8 shows the loadings of each feature or factor (water quality variables) for PC1. From the values of the loadings of the features for PC1 $(98.02 \%)$, it can be remarked that the difference between the three groups (clusters) was due to $\mathrm{K}^{+}$concentration and water temperature. However, $\mathrm{NO}_{3}-\mathrm{N}, \mathrm{NH}_{4}-\mathrm{N}, \mathrm{EC}, \mathrm{pH}$ and TDS were also contributed to the loadings value. These variables are related to the inorganic elements in chemical fertilizers ( $\mathrm{N}$ and $\mathrm{K})$.

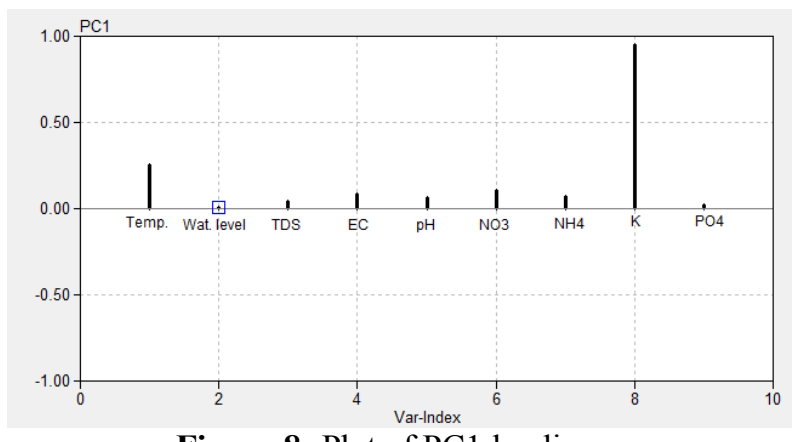

Figure 8: Plot of PC1 loadings.

Based on the monitoring wells clusters (Fig. 9), it can be concluded that nutrients which are nitrogen and potassium has been the major factor in the classification. Among the three clusters, Cluster 3 has the highest average $\mathrm{K}^{+}$and $\mathrm{NO}_{3}-\mathrm{N}$ concentration, as well as TDS and EC values; followed by Cluster 1 and Cluster 2 . However, for $\mathrm{NH}_{4}-\mathrm{N}$ concentration, the highest was in Cluster 2, followed by Cluster 3 and Cluster 1 . This result confirmed that the quality of groundwater could not be deduced by the type of aquifer. The application of cluster analysis (CA) and principal component analysis (PCA) have reduced the complexity of large data sets and proven to give a better interpretation and understanding of water quality data. If there is future work, sampling could be carried out from one from the each cluster (group member) to save time.

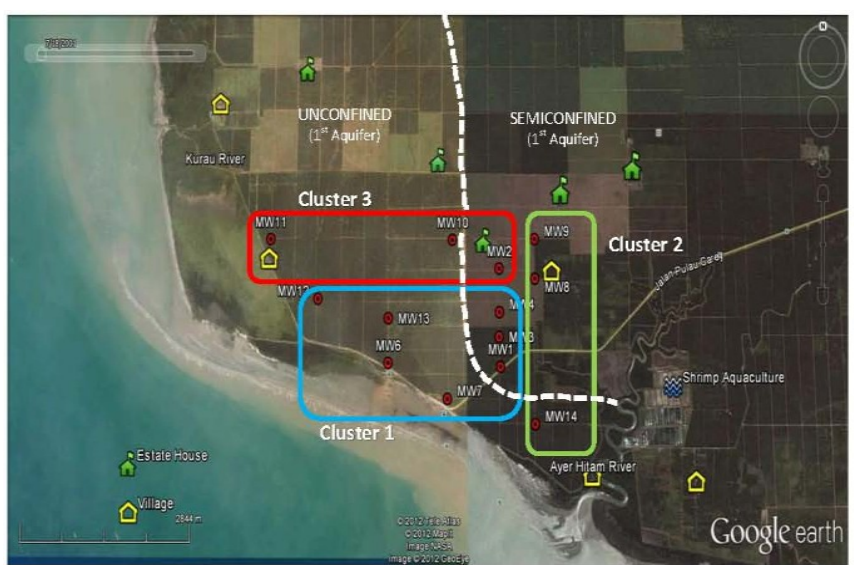

Figure 9: Spatial distribution of groundwater quality clusters.

\section{Conclusion}

There are two highlight findings in this study which are intensive agricultural activity in the island leave chemical residue in the groundwater; hence it is hard for the authorities to get freshwater source for the local people. The high concentration of $\mathrm{NO}_{3}-\mathrm{N}, \mathrm{NH}_{4}-\mathrm{N}$ and $\mathrm{K}^{+}$in the groundwater is believed because of the prolong usage of fertilizers at the oil palm plantation. It is also a concern if run-off from the groundwater might pollute the coastal area and affect the aquatic organisms. Secondly, the use of chemometrics / environmetrics for 
data interpretation in order to study the effects of long-term mixed land use of human settlement and oil palm plantation gave better understanding on the groundwater quality than comparison on type of aquifers.

\section{Acknowledgements}

This research was conducted with permission by Sime Darby Plantation. The authors wish to express their sincere thanks for the funding support received from HIR-MOHE University of Malaya under Grant UM.C/HIR/MOHR/ENG/34 and Vote IPPP (PV057/2011B) University of Malaya. The authors also wish to thank Associate Professor Zubaidah Ismail for editing the manuscript throughout the review process.

\section{References}

[1]. D.S. Ngah, Groundwater investigation for determination of suitability using handpumpat rural area of Kuala Langat District, Selangor DarulEhsan, Report No. GPH1/1988.(Department of Mineral and Geosciences Malaysia, Ministry of Natural Resources and Environment, 1988).

[2]. R. Ismail, Construction and exploration of deep wells at Carey Island and KgKelanang, Kuala Langat District, Banting Selangor. National Groundwater Resources Studyunder Subproject groundwater resources for State of Selangor. (Report done by KS GlobalSdnBhd with collaboration Multical Card (M) SdnBhd under instruction the Department ofMineral and Geoscience Selangor State, Malaysia, 2008).

[3]. M.F.T. Baharuddin, S. Taib, R. Hashim, M.H.Z. Abidin, M.F. Ishak, Time-lapseresistivity investigation of salinity changes at an expromontory land: a case study of CareyIsland, Selangor, Malaysia, Environ. Monitor. Assess. 180(1-4), $2010,345-369$.

[4]. M.F.T. Baharudin, Z. Ismail, S.Z. Othman, S. Taib, R. Hashim, Use of time-lapseresistivity tomography to determine freshwater lens morphology. Measurement, 46(2), 2013, 964-975.

[5]. S. Igroufa, R. Hashim, S. Taib, Mapping of salt-water intrusion by geoelectrical imaging in Carey Island, Proc. 5th Int. Symp. Hydrocarbons \& Chemistry (ISHC5), SidiFredj, Algiers, 23-25 May 2011.

[6]. S.M. Shirazi, M.A. Islam, Z. Ismail, M. Jameel, U.J. Alengaram, A Mahrez, Arsenic Contamination of Aquifers: Detailed Investigation on Irrigation and Potability, Sci. Res. Essays, 6(5), 2011, 1089-1100.

[7]. Z. Ismail, B. Primasari, S.M. Shirazi, Monitoring and Management Issues of Heavy Metal Pollution of Gombak River, Kuala Lumpur, Int. J. Phy. Sci., 6(35), 2011, 7961-7968.

[8]. Z. Ismail, K. Salim, S.Z. Othman, A.H. Ramli, S.M. Shirazi, R. Karim, S.Y. Khoo, Determining and comparing the levels of heavy metal concentrations in two selected urban river water. Measurement 46(10), 2013, 4135-4144. doi:10.1016/j.measurement.2013.08.013

[9]. Z. Ismail, R. Sulaiman, S.M. Shirazi, B. Primasari, R. Karim, Evaluating trends of water quality index of selected Klang River tributaries. EEMJ (2013).Accepted 25 April 2012.

[10]. J.C. Rozemeijer, H.P. Broers, The groundwater contribution to surface water contamination in a region with intensive agricultural land use (Noord-Brabant, The Netherlands). Environmental Pollution, 148, 2007, 695-706.

[11]. Z. Ismail, S.Z. Abdullah, B., Primasari, S.M. Shirazi, R. Karim, Issues and public awareness of landfills in Malaysia with a focus on post-closure development, EEMJ (2013). Accepted 10 May 2013.

[12]. Z. Ismail, R. Hashim, Seepage of contaminants from waste containment, J. Environ. Hydrol. 14(Paper 9), Aug 2006.

[13]. Z. Ismail, S.Z. Abdullah, S.Z. Othman, S.M. Shirazi, R. Karim, Assessment of the relative adequacy of landfills as a means of solid waste disposal in Malaysia, CLEAN - Soil, Air \& Water, 2012. doi: 10.1002/clen.201200316

[14]. P.M. Barlow, E.G. Reichard, Saltwater intrusion in coastal regions of NorthAmerica, Hydrogeol. J. 18, 2010, $247-260$.

[15]. Z. Ismail, N.A. Aziz, R. Hashim, Seawater intrusion into groundwater: Peninsular Malaysia, J. Environ. Hydrol. 15, $2007,1-8$.

[16]. Z. Ismail, R. Karim. Some aspects of spills in the sea transportation of petroleum materials, Safety Sci. 51(1), 2013, 202-208.

[17]. Z. Ismail, J.C. Tai, K.K. Kong, K.H. Law, S.M. Shirazi, R. Karim, Using data envelopment analysis in comparing the environmental performance and technical efficiency of selected companies in their global petroleum operations, Measurement 46(9), 2013, 3401-3413.doi: 10.1016/j.measurement.2013.04.076

[18]. Z. Ismail, N.A. Aziz, R. Hashim, Monitoring VOC concentrations in groundwater: Peninsular Malaysia, J. Environ. Hydrol.16(Paper 3), 2008.

[19]. Z. Ismail, A.H. Ramli, S.D. Somarin. Lessons learnt from accidents in downstream petroleum product processing and handling, OilGas Eur. Mag. 38(3), 2012, 157-162.

[20]. E. Rodriguez, R. Sultan, A. Hiliker, Negative effects of agriculture on our environment, The Traprock 3, 2004, 28-32.

[21]. S.M. Shirazi, Z. Ismail, S. Akib, M. Sholichin, M.M.A. Islam, Climatic parameters and net irrigation requirement of crops, Int. J. Phy. Sci. 6(1), 2011, 15-26.

[22]. Z. Ismail, K. Salim, Determination of critical factors in implementing river clean-up projects: a Malaysian case study, CLEANSoil, Air \& Water41(1), 2012, 16-23.doi: 10.1002/clen.201000562

[23]. S.M. Shirazi, J. Kuwano, H. Kazama, S. Wiwat, Z. Ismail, Response to Swelling and Permeability of Bentonite using Saline Solution for Nuclear Waste Disposal, Disaster Adv. 4(1), 2011, 41-47.

[24]. Z. Ismail, A.M. Bedderi, Potential of water hyacinth as heavy metal removal agent from refinery effluents, J. Water Air Soil Pollut. 199(1-4), 2009, 57-65.

[25]. Z. Ismail, S.Z. Othman, K.H. Law, A.H. Sulaiman, R. Hashim, Comparative performance of water hyacinth and water lettuce in preventing build-up of nutrients in municipal wastewater, CLEAN-Soil, Air \& Water,2013. doi: 10.1002/clen.201200254

[26]. American Public Health Association (APHA), Standard Methods for the Examinationof Water and Wastewater.18th Edition.(Washington D.C., 1992).

[27]. G. K. Reid, R. D. Wood, Ecology of inland waters and estuaries. $2^{\text {nd }}$ Edition.(D. Van Nostrand Company, New York, 1976)485pp.

[28]. J. S. Ogeh, G. E. Osiomwan, Evaluation of the effect of oil palm on some physical and chemical properties of Rhodicpaleudults, Nigerian Journal of Basic and Applied Science, 20(1), 2012, 78-82.

[29]. H. Juahir, S. M. Zain, M. K. Yusoff, T. I. T Hanidza, A. S. M. Armi, M. E. Toriman, M. Mokhtar, Spatial water quality assessment of Langat River Basin (Malaysia) using environmetric techniques,Environmental Monitoring Assessment, 173, $2011,625-641$.

[30]. A.Z. Aris, M.H. Abdullah, K.W. Kim, Hydrogeochemistry of groundwater in Manukan Island, Sabah, Malays. J. Anal. Sci. 11(2), 2007, 407-413.

[31]. A.Z. ArisS.M. PraveenaM.H. Abdullah M. Radojevic, Statistical approaches andhydrochemical modelling of groundwater system in a small tropical island,J. Hydroinformatics 14(1), 2012, 206-220. 